\title{
クモ膜霊腫の臨床病理学的検討
}

\author{
津田 敏雄・上田 伸・松本 圭蔵

\section{Clinicopathological Study of the Arachnoid Cyst}

\author{
Toshio Tsuda, Shin Ueda and Keizo Matsumoto \\ Department of Neurosurgery, Tokushima University, Tokushima 770
}

\begin{abstract}
Summary
Twenty-one cases of arachnoid cysts were experienced in the last 5 years. Craniotomy and extirpation of the arachnoid cysts were performed on 20 cases.

Clinical features and histological findings of these cases were investigated. Ages of these patients ranged from 7 months to 70 years. Twelve cases $(57 \%)$ were under the age of 20 years and the other nine cases $(43 \%)$ were over 20 years old. The cysts were located in the middle fossa in 12 cases, in the frontal lobe in five cases, in the posterior fossa in three cases and in the left-sided hemisphere in one case. Symptoms were generally rather mild.

Among the 12 cases of middle fossa arachnoid cysts, only six cases showed bony changes such as elevation of the sphenoid wing in plain skull films and of the 11 cases which underwent angiographic studies, only five cases showed poor visualization of the superficial middle cerebral veins on the affected side. Arachnoid cysts were readily diagnosed by CT examination as watery low density areas with a clear-cut margin which showed no enhancement by intravenous injection of contrast media.

Metrizamide-CT and RI-cisternography were utilized in nine cases. Eight cases showed non-communicative cysts surrounded by metrizamide acummulation in the adjacent arachnoid space.

Histological examinations of the cystic membrane were performed in eight cases by taking specimens from the covering part as well as from the bottom where the membrane adhered to the cortical surface. Seven out of eight cases showed duplicated normal arachnoid membrane. This finding indicated that the cysts could be regarded as "intraarachnoid cysts", as pointed out by Starkman.

Normal arachnoid membrane was examined histologically by taking specimens from lobectomized cortex as well as autopsied brain for comparison with the cystic membrane.

These examinations revealed an interesting arachnoidal structure which might be termed "micro-intraarachnoid cysts" in certain instances. The etiology of the primary arachnoid cyst has been considered as congenital or developmental in nature. Starkman advocated that the structure of the intraarachnoid cyst itself indicated congenital malformation of the arachnoid membrane.

However, this series included so many unexpected adult cases and also a case of posttraumatic arachnoid cyst in one identical twin. Therefore, one course of pathogenesis of the arachnoid cysts, can be postulated as a "microintraarachnoid cyst" existing in normal people starting to grow and becoming a large arachnoid cyst, triggered by some enlarging forces in head traumas or other unknown factors.
\end{abstract}

Key words: arachnoid cyst, metrizamide CT cisternography, arachnoid membrane

徳島大学脳神経外科

〔連䅂先： =770 徳島市藏本町3-18-15, 徳島大学䏚神経外科，津田敏雄]

1980年 5 月12日 受稿 


\section{Iはじめに}

クモ膜襄腫 (arachnoid cyst) は, 1831年 Richard Bright の報告以来，その報告はところどころに散見され，頭蓋 内占拠性病変の約 $1 \%$ を占める比較的稀なものと考えら れてきた，しかし，CT 導入以後，本症の診断がきわめ て容易となった現在，その症例数㑑加する傾向がみら れ，かつその病理や臨床像につき再検討される心゙き時期 にあると考えられる。我々は21例のクモ膜装腫を経験し たので,これらの症例の臨床像, さらには病理学的所見 につき榆討を加え, 若干の知見を得たので報告する.

\section{II症例の検討}

1975年 6 月より現在までの 5 年 10 力月間に，当教室杧 よびその関連病院にて経験したクモ膜囊腫は 21 例であ る。そのうち，metrizamide CTにて，明らかにクモ膜 下腔と䅹腫の間に交通が認められた2例中，中頭蓋简の 1 例を除く20例代開頭手術を行った（Table 1).

1. 年令, 性別, 部位について
年令注，生後 7 力月から 70 才までにわたっており，20 才以下の症例は12例 (57\%) であった (Fig. 1)

性別に関しては男性 14 ：女性7で，男性が女性に比乙 2 倍の高頻度であった。

襄腫存在部位は，側頭部にもっとも多く12例で，左側 は8 例，右側は 4 例であった，前頭部に局在したものは 5 例で，左側 3 例，右側 1 例，両僋にみられたもの 1 例 であった，後頭蓋窩のものは 3 例で，これらはいずれも 正中部に存在した．また右側大脳半球全体に搪がった形 を呈した1例があった（Fig．2)．また，この例に阽いて は街後 S-Pシャントを設置し，覆腫の消失をみた (Fig. 3).

\section{2. 初発症状および臨床的所見}

初発症状抒よび主症状としては，頭痛がもっとも多く 10例（側頭部 7 例，後頭蓋容 2 例，前頭部 1 例）で，そ のほか㽷藥発作 7 例（側頭部 4 例，前頭部 3 例)，目まい 2 例，小腷性失調 $\mathrm{l}$ 例，尿失禁 $\mathrm{I}$ 例，不全片麻㾝 1 例な どがみられた (Fig. 3)、この上らに，本症に招いて特定 の症状というもの快みらなかったが，いずれの症状む

Table 1 Clinical profiles of cases with arachnoid cysts

\begin{tabular}{|c|c|c|c|c|c|c|}
\hline Case & Age & Sex & Trauma & Location & Symptom & Operation \\
\hline 1. & $8 Y$ & $\mathbf{F}$ & + & Lt. middle fossa & Headache & fair \\
\hline 2. & $9 \mathrm{Y}$ & $\mathbf{M}$ & - & " & Convulsion & good \\
\hline 3. & $11 \mathrm{Y}$ & $\mathbf{M}$ & + & $"$ & Convulsion & good \\
\hline 4. & $11 \mathrm{Y}$ & $\mathbf{F}$ & - & $"$ & Convulsion & good \\
\hline 5. & $15 \mathrm{Y}$ & $\mathbf{M}$ & - & $"$ & Headache & none \\
\hline 6. & $18 \mathrm{Y}$ & $\mathbf{F}$ & + & $"$ & Convulsion & fair \\
\hline 7. & $44 \mathrm{Y}$ & $\mathbf{M}$ & + & " & Headache & fair \\
\hline 8. & $70 \mathrm{Y}$ & $\mathbf{M}$ & - & $"$ & Headache & fair \\
\hline 9. & $8 Y$ & $\mathbf{M}$ & + & Rt. middle fossa & Headache & good \\
\hline 10. & $9 \mathrm{Y}$ & $\mathbf{M}$ & - & $"$ & Headache & good \\
\hline 11. & $43 \mathrm{Y}$ & $\mathrm{F}$ & - & $"$ & Headache & good \\
\hline 12. & $58 \mathrm{Y}$ & $\mathbf{F}$ & + & $"$ & Convulsion & good \\
\hline 13. & $7 \mathrm{M}$ & $\mathbf{M}$ & - & Lt. frontal & Convulsion & good \\
\hline 14. & $9 \mathrm{M}$ & $\mathbf{M}$ & - & $"$ & Convulsion & good \\
\hline 15. & $68 \mathrm{Y}$ & $\mathrm{F}$ & - & $"$ & $\begin{array}{l}\text { Urinary } \\
\text { incontinence }\end{array}$ & good \\
\hline 16. & $44 \mathrm{Y}$ & $\mathbf{M}$ & + & Rt. frontal & Headache & good \\
\hline 17. & $63 \mathrm{Y}$ & $\mathbf{M}$ & - & Bi-frontal & Convulsion & fair \\
\hline 18. & $8 \mathbf{Y}$ & $F$ & - & Posterior fossa & Cerebellar ataxia & fair \\
\hline 19. & $36 \mathrm{Y}$ & $\mathbf{M}$ & + & " & Headache, vertigo & good \\
\hline 20. & $38 \mathrm{Y}$ & $\mathbf{M}$ & - & $"$ & Hcadache, vertigo & good \\
\hline 21. & $2 \mathrm{Y}$ & $\mathbf{M}$ & - & Lt. hemisphere & Motor weakness & fair \\
\hline
\end{tabular}


そら重篤なものとの印象を与えなかった点にその特徴が あると思われた。

\section{3. 外侮の既往について}

21例において，外傷の既往を聴取できたの仕 9 例（43 \%)であった，外傷の程度，部位などから，外傷にて発 生したいわゆる続発性のむのと考えられたのは2例 (Case 6，16) であり，その他のものは一底原発生とし た。 また，それ以外に出血，感染，腫瘍などとの関倸が 考えられる症例はなかっった。

\section{4. 神経放射線学的検討}

頭蓋単純撮影において，側頭部クモ膜震腫 12 例の5 ち，側頭鱗の菲薄化扰よび sphenoid wing の挙上がみら

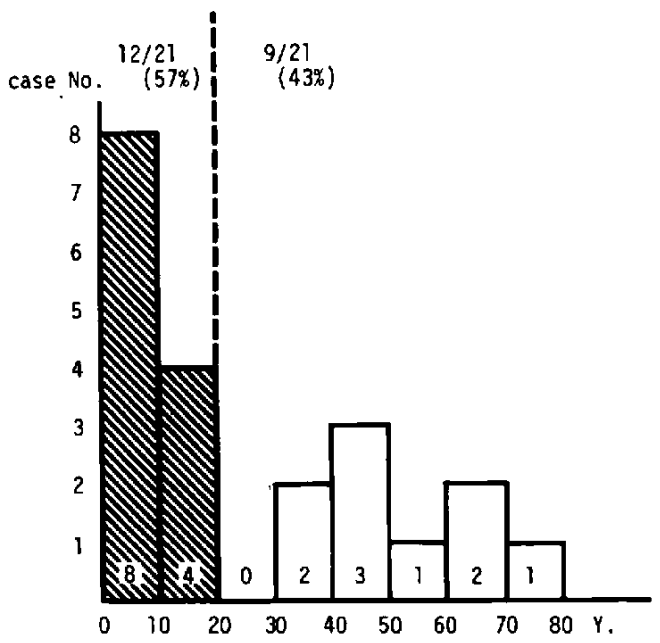

Fig. 1 Age distribution in our 21 cases of arachnoid cysts.
れたものは6例であった。この骨変化のみられなかった 6 例は，20才以上の成人例ないしは襄腫の比較的小さい 例であった（Fig. 4). 束た，前頭部，後頭蓋窩にクモ膜 軎腫の局在をみた例では認む心゙き骨変化はなかった。な 㕲左大脳半球全周に摭がった 1 例では，同側の頭蓋の摭

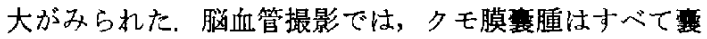
腫存在部位に一致する無血管野としてとらえられたが， その近傍を走る主翰動脈の著しい偏位をみたものは 2 例 のみであった，さらに，側頭部のクモ膜嚢腫の血管写所 見として，浅中大脳静脈の久損がみられると一般に言わ れているが，この部の震腫で譄血管撮影を行った11例を 検討したところ，6例において同静脈性比䡈的明僚にみ られた (Fig. 5).

さて, CT スキャンでは，クモ膜事腫の局在と一致し

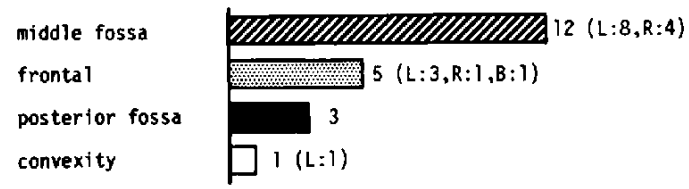

headache
convulsion
vertigo
$\begin{aligned} & \text { cerebellar ataxia } \\ & \text { urinary } \\ & \text { incontinence } \\ & \text { hemiparesis }\end{aligned}$

Fig. 2 Locations and cardinal symptoms of 21 cases.

L: left, R: right, $B$ : bilateral

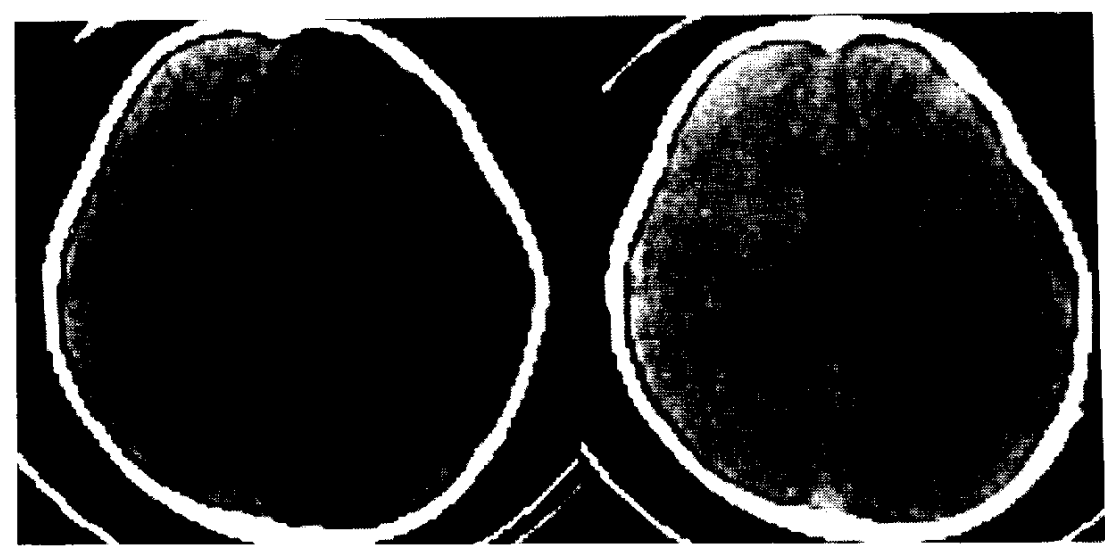

preoperative postoperative

Fig. 3 CT scans of rt. convexity arachnoid cyst (Case 21). A large low density arca was noted with marked midline shifting (preoperative CT). The low density area disappeared completely after the operation. 


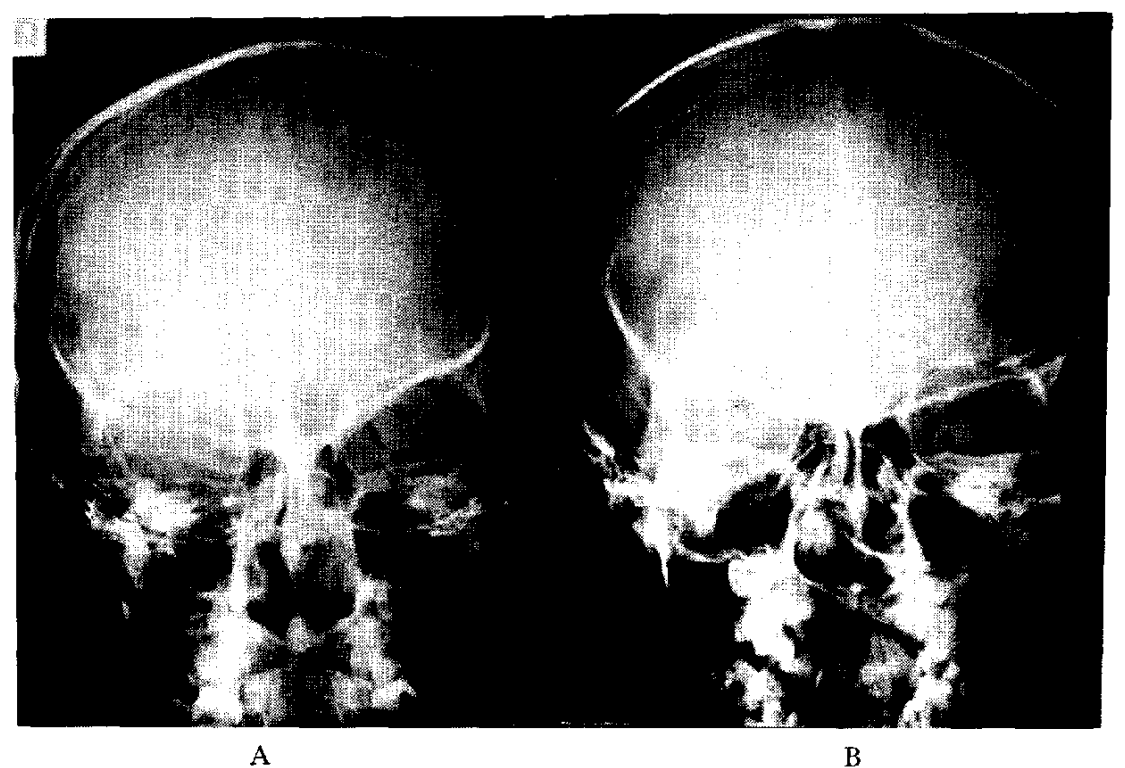

Fig. 4 Plain skull X-ray of middle fossa arachnoid cyst. Six out of 12 cases showed unilateral elevation of the sphenoid wing on the affected side as seen on the left $(\mathrm{A})$.

The other cases demonstrated no or only minor changes of the sphenoid wings as shown on the right (B).

た部に，明僚な水とほぼ同程度の吸収倸数をむつ low density areaが認的られた。これらはcontrast enhancement では増強されなかった (Fig. 6).クモ膜下腔上垔堹の間 の交通性の有無を検討するため，9例に metrizamide CT，または RI cisternography 施行したが，側頭部の 1 例, 後頭蓋窝の 1 例代おいて交通性があることが認め られた，その他の7例に㧤いては, metrizamide や RI

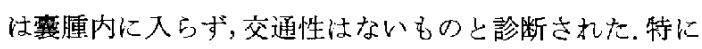
交通性のなかった囊腫では, metrizamide CTにて, 䔩腫 周囲のクモ膜下腔に霊腫を取り困をよらに metrizamide が流入している像がみられたすななるら慗堙の周囲に正 常なクモ膛下腔が存在することが示された（Fig. 7)。 ま た，側頭部クモ膜轅腫で交通性のみられた 1 例 (Casc 5) は，前述のごとき手術は行わず経過観察することとし た.

\section{5. 病理学的検討}

開頭手術時にはなるべく多くのクモ膜をできるだけ 1 校の膜として切除するよう心がけ，これ炕より採取しえ た囊腫被膜について検討した，一般に囊腫の下壁，すな わち篦表と接する面は瘾着が強く、これ省採取しえたの は10例にとどまった．また，神経学的欠椇を残さぬ部で は，被膜小片を脳実質の一部とともに切除した，襄腫上 壁は手術例全例に採取した，標本はなるべく重畳しない ように留意しつつ固定し，切片を作成した，そり光顕所
見は正常のクモ膜とよく類似していたが，強拉大にする と2 層または数層のクモ膜が重なっている所見がみられ た、襄腫下壁の標本に扔いてもまたクモ膜がみられた (Fig. 8). 下壁の検討に标いては，組織学的にクモ膜の みられなかったものが 3 例あった。このよ5な例は subarachnoid cyst とも考えられたが, metrizamide CT の可見などからむしら標本採取時や固定時に，肉眼で は見えにくいような被膜が脳実質小片から脱落したこと に上る可能性もあると考えられた，さて，この襄庫被膜 の組織像を比较検討するため, 脳腫瘍摘出時, やもなく 正常と思われた前頭葉ないし側頭集の lobectomyを行っ た例の新鮮な標本，あるいは剖検に拉けるクモ膜の標本 など10例に関して正常と思われる部のクモ膜を検討した ところ，2 例に扔いて小さなcyst を形成している所見 がみられた (Fig. 9).才なわち，1 層であるべきクモ膜 がある部分で一部 2 層に分離, または折れ曲がり重冨し ヶ, 一見 micro-intra-arachnoid cyst ともいうべき形態 をもつものがあることが認められた. しかし、この小囊 胞の存在は技術上の問題から一連の連続切片により確認 されたものではないが，少なくともこの唾胞様所見を呈 した近辺の 2，3の切片標本の検討では䒼胞と考光られ た. 
A

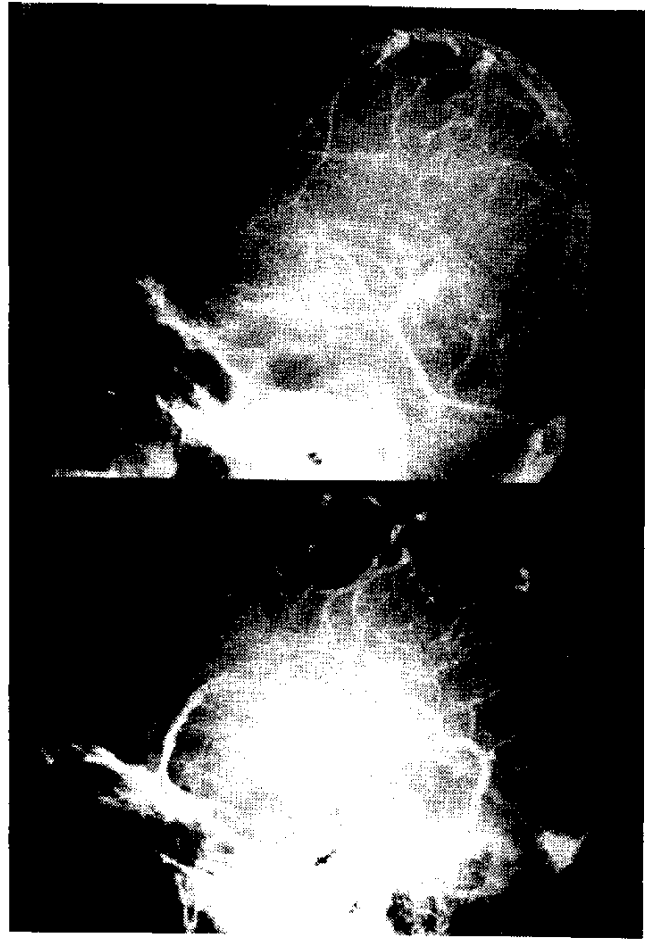

Fig. 5 Angiographic study of the superficial middle cerebral veins. These veins were poorly visualized (A) in 5 out of 11 cases of middle fossa arachnoid cysts. The veins were identified clearly in the remaining 6 cases (B).

\section{II 臨床的考察}

1. 頻度, 性別, 年令に関して

本症の覑度に関して Robinson ${ }^{17}$ は，広義頭蓋内腫場 の $1 \%$ 以下と報告しているが，我々の21例は，過去 4 年 間に当教室において経験した全頭蓋内腫瘍 435 例のうち 4.8\%を占めて抢り，従来の報告に柇沙度よりやや 多いようである。また性別に関しても，Faris ら”は： 1，Robinson ${ }^{17}$ は7：1 といずれも里性に多いとされて いる。我々の検討に拝いても21例中14例が男性であり同 様の傾向がみられた。また年令に関しては，一般に20才

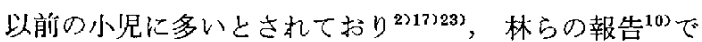
も12例す心゙てが小児であったとしている。そして，この 若年者に多発するといらことが本症学先天性と考える1 つの基盤にもなっているようである，しかし，我々の祉 例をみると，20才以前のものが12例，20才以後の成人例 が9例であり，若年者に多い傾向法認少られるが，成人 例でも約半数近くの率 $(43 \%)$ を占めて扔り，必ずしも 小児に特に多いといらこと注できないのではないかと思

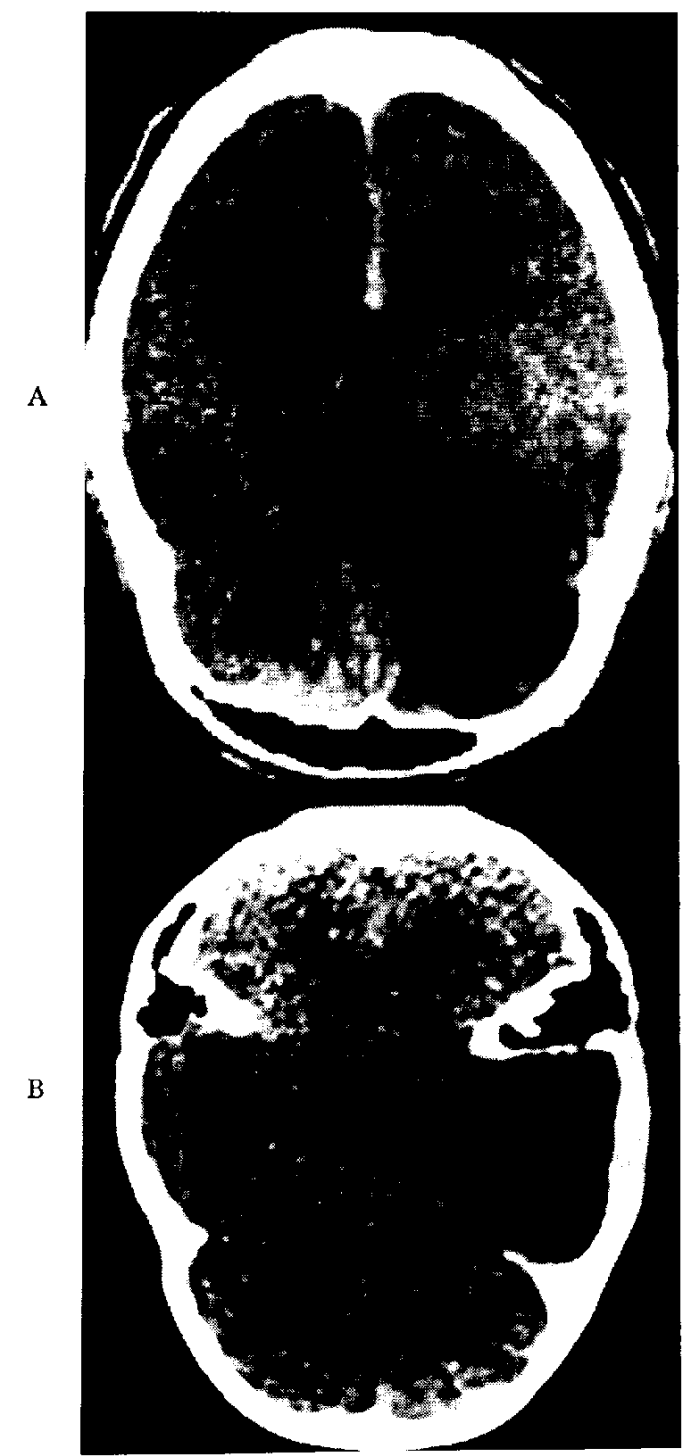

Fig. 6 CT scans showing clear low density areas in cases of arachnoid cysts.

A: lt. middle fossa arachnoid cyst.

B: 1t. frontal lobe arachnoid cyst.

われた，事寒最近では，成人ょよび高命者例の報告も多 $\left\langle{ }^{33719310\rangle 20\rangle 25\rangle}\right.$, Smith ${ }^{20}$ 沈，6例の arachnoid cyst ち4例までが成人例であったとしている：このことは， CT スキャンなどによりその診断が比較的容易となった 現在，好発年令および年令分布などに関しても，再考の 必要があることを示唆しているよらに思える。

\section{2. 部位および臨床症状に関して}

Robinson の 25例の統計 ${ }^{17}$ では, middle fossa 16 例, 


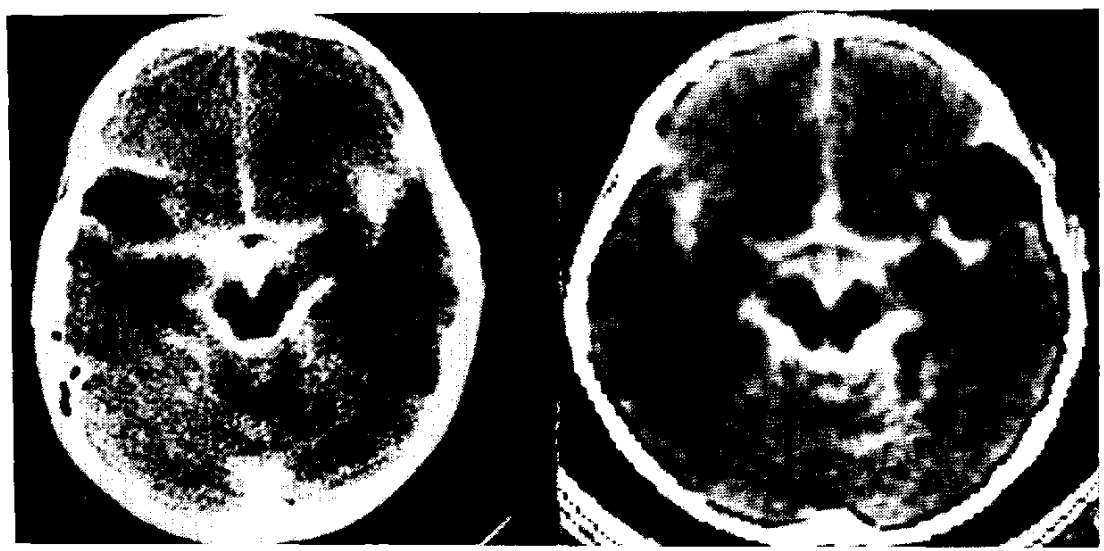

Fig. 7 Metrizamide CT scans.

In these cases, metrizamide is not seen in the cysts.

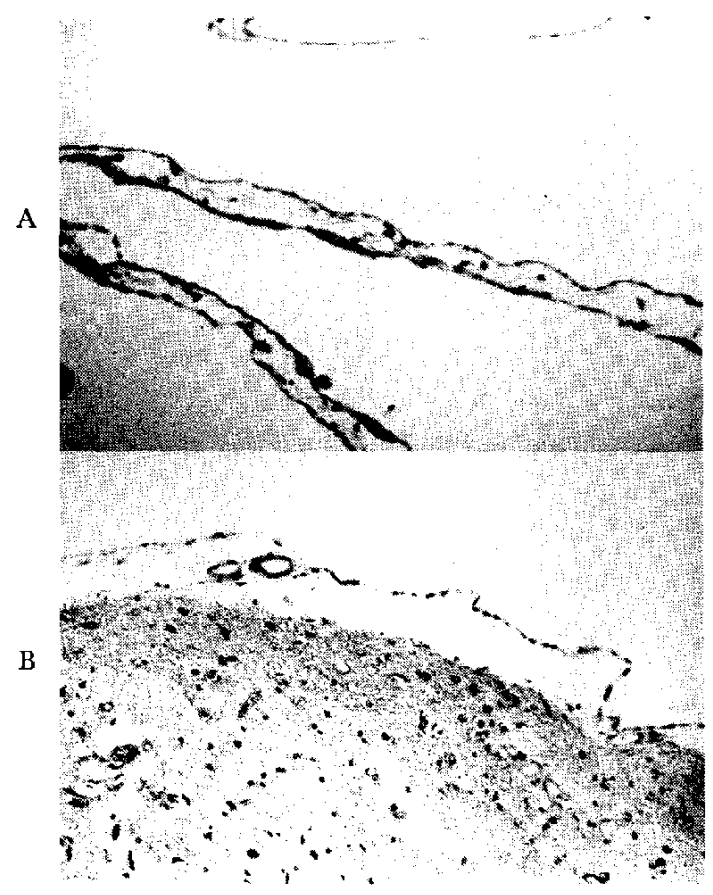

Fig. 8 Microphotographs of the roof (A) and the bottom of an arachnoid cyst (B). Both membranes showed nearly normal structure of the arachnoid membrane.

cerebral hemisphere 3 例, paracollicular 2 例, posterior fossa 4 例となって拈り，その他の報告では sella turcica にあるもの ${ }^{16)}$, sylvian fissure にあるもの などの報告 があり，必ずしも好発部位というものはなく，arachnoid membrane のあるところならどこに発生してむいいとす

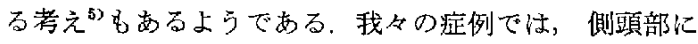

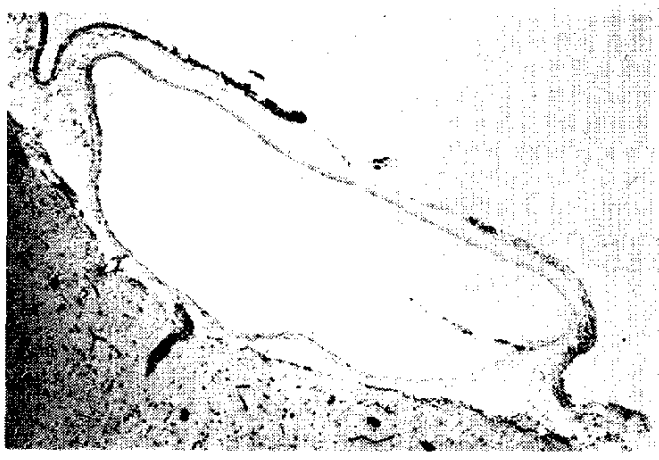

Fig. 9 Microphotograph of a so-called "microintra-arachnoid cyst" which was noted in the normal brain section.

もっとも多く，ついで前頭部に多いとい5結果を得てい る。これら側頭部，前頭部になぜ多いかに関しては不明 であるが，この部が外傷江際してもっとも稘害を受けや すい部であることを考えれば，本症の発生执よび增大 と，あるい性気付かれない程度の軽微な外傷との間に何 らかの関係があるのかも知れないと推測でき，きわめて 興味深い，また，Case 6 は一即生双生韭の姉例で，乳児 の頃転落事故の既往歴があり，またその妹はまったく正 常であったこ上より本例を先天性のもの上するより，外 傷性であることを強く疑わしめる例であった：この例に 関しては，才でに詳細な検討を行い報告している゙が.

臨床症状に関しては，一般に頭痛がもっとも多い1017 とされて抢り，その他，うっ血乳頭などの頭蓋内圧九進 症状，また cyst 存在部位に一致した小暚症状や, posterior fossa arachnoid cyst そらられれ parkinsonian-like syndrome ${ }^{14)}$ など種々のものがあるが，一方，まったく無 
症状に経過し，剖検時，または CT スキャンにより偶 然発見された例10130もあるようで，本症に特街的症状と いらものはあまりなく、この点に関してもCTスキャン の普及により，さらに症例を重好詳細な検討がなされる べきであろう。

\section{3. 補助検查に関して}

従来, 本症の診断には,まず頭蓋単純撮影における変形 を証明することが重要であるといわれている゙510>27?. 特に middle fossa arachnoid cyst に関しては, 側頭鱗の菲 薄化，膨隆，扰上びsphenoid wing の挙上2)21031115)1719)23》 が特徽的であるとされている。しかし，我々の症例にお いては,これら骨変化のみられたもの注 middle fossa arachnoid cyst 12例中の 6 例と, 患側頭蓋の拡大の認め られた hemisphere 全周にわたる大きなcyst を有した1 例 (Case 21) であった。骨変化のみら扎なったのは， いすれも20才以上の成人例か，あるいは变腫が比較的小 さなものであった。 もらろん過去の報告でも頭蓋単純撮 影でなんら所見のなかった例るみられる とより，この骨変化は霍腫が頭蓋内占扰性の病変として の性格をもった時期が骨発育の時期であることや，その 大きさも関係してあらわされる二次的病変であるらと考 えられた．また，递血管撮影の所見は，䧶腫の存在部位 に一致する無血管野, その他の占执性病変としての所見 に加えて，特に中頭蓋简のそれは浅中大媨静脈の造影欠 損9110)1115223)が特徴的とされている. 玉木らはこの所見 に注目し，本症発生の原因をこれに求め，胎生期に招け る脳静脈采の灌流障害が大譄半球の発達停止を引き起こ L,この部に襄胞性病変を発生させた，以わば“developmental arrest of the cerebral mantle” の状態であると 推論している ${ }^{23)}$. しかし, 我々の症例の検討では, 前述 のごとく脳血管写を行った11例中，浅中大媨静脈が造影 不良であっためのは 5 例で，他の6 例は比較的良好であ った.なお，このうち1例では(Case 3)，亯腫の後部に 圧迫偏位された浅中大腷静脈を脱血管写で認め，手術時 に確かめられたことなどからこの血管系の異常が常に 鉒腫に先行して存在する本質的なものであるとは考えに くく，単に脳実質が俥腫により圧迫されたり，あるいは そのため発育不良になって血波の流出路を必要としない ための結果であろうと考えられた。 そして，その程度も しくは血液循環動態の個人差のために，これら静脈が造 影される場合とされない場合があるのではないかと思わ れた，CTスキャンに関しては，その診断に㧍ける信頼 度は決定的ともいえる。すなわち素腫は水と同程度の吸 収係数をむつ low density area として認如られ，しかも 造影用による contrast enhancement 認められないとこ
ろに特徴がある ${ }^{327202}$. また，整胞内腔とクモ膜下腔と の間の交通の有無を検索することは治療上きわめて重要 なことであると思われ，その目的のためには RI cisternography， metrizamide CT が有用である. RI cisternographyによる検討において，菅沼らは 6 例の primary arachnoid cyst に関し, 全例 cyst 内一のRI の流入を み，同時に胞内腹内 RI流入，流出時間の遅延がみ られたと報告している。しかし一方，車腫内一 RIの取り 込みがみられなかったとする例の報告”や, metrizamide CTにより流入が確認できなかったといら報告 ${ }^{100}$ む る。我々の例においては，9例中 7例がこれら検查にて 售腫内とクモ膜下腔との間の交通がみられなかったこと より，Robinson らが主張した subarachnoid cyst である とする説 ${ }^{17}$ は納得しがたい上5に思われた. 特にFig. 8 に示したように, metrizamide CTにて車腫の外周に metrizamide がこれを取り囲もように流入する所見は， その車腫の外周に正常クモ膜下腔が存在するといらこと を意味し, Starkman ら 2 層に分嚄した形で霓腫が形成されているとすることは 困難であ万う。生た，2例の交通の認められた例では， subarachnoid cystであるとするより，本来交通のなかっ たものがなんらかの機転で露腫の壁の一部が破机たため 交通性となったとも考えられる。

\section{N 病理学的考察}

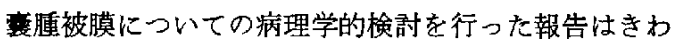
めて少ない、これは単に衰胞と媨室との短絡術のみ行わ れる例もあることにもよろうが，開頭術を行った例にお

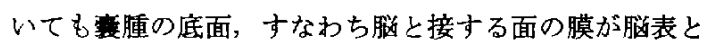
強く痽着していることが多く，剥離困難であること，ま た剖検例においても，軾腫を原形のまま取り出すことが 難しいことなどの理由からであらら.これらの理由から， 本症の病理学的立場からみた病因, 病態に関する検封に おいてもいまだ不明な点が多い(38)1317121》，さて一般に は，本症の発生機転に関して，大きくわけて原発性のる のと, 続発生(外傷, 炎症, 出血, 腫瘍などによる)のもの とにわけられているようである。そして，原発生という 意味は，むとると臨床的に明らかな原因が琶められない 例といら意味であるが，現在一般には原発性のものはほ とんど先天性のむのと考えられているよらである.すな わちこの考え方は, Starkman, Robinson らの考え方に 代表され，Starkman ${ }^{21}$ は，その剖検例上り，本来 1 層 であるべきクモ膜が 2 層に分離し，その中に得腫を形成 していたとする被膜所見加ら，いかゆる“intra-arachnoid cyst”がその本態であり，発生学的にクモ膜下腔の 
発生が媨の発達より早いことからます，クモ膜の奇形 が先行し，なんらかの機転て次第に雯腫腔の搪大を起こ して，それにより二次的に譄の発達障害がくるものと考 えた。すなわち，タモ膜の先天的奇形に立脚寸る考え力 である。 女51つの考え方は，Robinsonの提晿した “subarachnoid cyst”としての考え方である17, まず， なんらかの形での脳形成不全が起こり，その部のクモ膜 下腔の应大が起こり，徐々に大きくなりクモ膜整腫とな る上寸る考えである，そして，多くの場合，それは䫓蓋 内占拠物としての性格はもたず，タモ膜下腔との間には 交通があって，骨変化は髄液の拍動により生じたもので あるとした。これら先天性と考完る中にも2つの基盤を 異と寸る考えがあり，現在，どちらが本症の発生をよく 説明できるかは不明である。すなわち，その理由の1つ には，組織学的にこの整腫が “intra-arachnoid cyst” あると証明した報告は，Starkman 以外にはGhatak の72 才女性の部㭘例，Krawchenko の19才女性の剖检例，士 た，著者らの報告した68才女性における frontal arachnoid cystの 1 例などのわずかな報告をみるにすぎないか らである。今回我々は，手術時において露腫上壁，そし て可能であるかぎり杽表と接する下壁, 側壁をむ検討し たところ，10例中 7 例はいわゆる“intra-arachnoid cyst” であることが証明できた。生た，下壁にクモ膜がみられ なかった例でも，前述のごとくこれを“subarachnoid cyst”であると断定することはできなかった，我々が被 膜を检討した例のほとんどは，Starkman らのいらクモ 膜の異常による intra-arachnoid cyst であると考えられ た.

ところで，我々が正常成人脳に敌いて，そのタモ膜を 検討したところ，クモ膜の一部に小さな整腫形成がみら れ，いわゆる “micro-intra-arachnoid cyst”ともいらべ

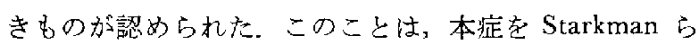
のいら胎生期に扔けるクモ膜の先天性奇形という考え以 外に，正常成人脳に狲ても，なんらかの原因に上り， ときに存在する“micro-intra-arachnoid cyst”が，ある条 件下または贫的機転一たとえば軽徴な外傷による事内人 の出血，襄胞の一部破錠による valve mechanism の発生 などの因子 (enlargement factor)一が加わって襄胞が搪 大し，臨床的にみられるっモ膜襄胞となるのではなかる らかと若えられた。 そして，このよらな考え力は，我々 の経験した症例の半数近くが成人ないし高令であったこ と，好発部位が外傷に際して損傷を受けやすい側頭部， 前頭部にあること，また，一毌性双生児であり，従来な らば先天性と若えてよい臨床的所見を呈した例 (Case 6) に挌いて，その妹は生ったく正常であり，明らかな外傷
との関連が示唆されたこととむ矛盾しない：またっこの

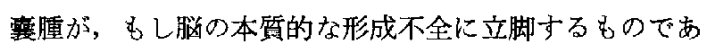
るとすれば，亭腫の減圧を行った後にCTスキャン所 見から㨫が再膨登し，裹腫の縮小ないし消失がみられた とする報告や，我々の手術後の CT スキャン开見の改 善と矛盾する点があるらと思われる。

本症の発生病理に関しては興味ある問題であり，今後 さらに症例を重机检討するつもりである。

\section{V ま と}

1. 過去 5 年間に当教室で経験した 21 例の arachnoid cyst に関して, 臨床一病理学的検討を加えた。

2. 症例は生後 7 力から70才までであり，20才以下 の若年者は12例 (57\%) であった.

3. 部位別䞄度は，中頭蓋窝におけるものが12例とも っとも多く, 前頭部 ( 5 例)，後頭蓋䆚 (3例)，片側大 脳半球全体に掂がるもの1例であった.

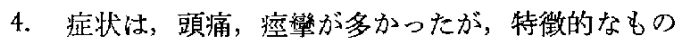
は認められなかった。

5. 補助検查法では，CT スキャンがもっとも有用で あり，脳血管撮影，頭蓋単純写においては特徴的なもの はなかった。

6. 襄腫被膜の検討に挍いて，上下面ともクモ膜がみ られたことよりこれは intra-arachnoid cyst であろう と思わ扎た

7. 正常と思わ狆る畄表を検索したところ，正常クモ 膜に小さな䇥腫形成（micro-intra-arachnoid cyst）がみ られたことより，本症発生增大の機序として,この micro-intra-arachnoid cyst がなんらかの因子 (外傷等) の関与のもとに增大し, arachnoid cyst として発症する むのと考えられた。

本論文の要旨は, 第38回日本媨神释外科学会棇会 (1979 年10月 東京)にて発表したが，最近，Schachenmayer ${ }^{18)}$ らは，9例の arachnoid cyst と正常クモ膜を電顕的に検 討し，その基本的な性格は，正常にもある trabecularの 局所的巽常にあるとしているがこの絬論は我々の考え とも合致する点が多い上うに思える。

\section{文献}

1) Arcardi, J. \& Bauman, F.: Supratentorial extracerebral cysts in infants and children. $J$ Neurol Neurosurg Psychiatry 38: 57-68, 1975

2) Anderson, F. M. \& Landing, B. H.: Cerebral arachnoid cysts in infants. $J$ Pediatr 69: 88-96, 1966 
3) Anderson, F. M., Segall, H. D. \& Caton, W. C.: Use of computerized tomography scanning in supratentorial arachnoid cysts. $J$ Neurosurg 50: 333-338, 1979

4) Berkmen, Y. M., Brucher, J. \& Salmon, J. H.: Congenital arachnoid cysts. $A m J$ Roentgenol 105: 298-304, 1969

5）虻名国彦，三田禮造，鈴木重晴：原発性クモ 膜鸾腫の成人例。脳外 $4: 89-94,1964$

6) FARIS, M. D. M.: Bitemporal bulging and thining of the skull. Virgina Med Month 93: $80-83,1966$

7) Geissinger, J. D., Kohler, W. C., Robinson, B. W. \& DAvts, F. M.: Arachnoid cysts of the Middle Cranial Fossa, Surgical Considerations. Surg Neurol 10:27-33, 1978

8) Ghatak, N. R. \& Mushrush, G. J.: Supratentorial intra-arachnoid cyst. $J$ Neurosurg 35: 477-482, 1971

9) 林 隆士, 宮武 潤, 河井宏一, 馬場繁幸, 渡辺光夫，倉本進賢：頭蓋简クモ膜の5腫に関 する臨床的考察．遒神释29:1177-1187，1977

10）林 隆士，姉川繁敬，本田英一郎，倉本進賢， 森 惟明, 村田高穂, 三輪聡一, 半田 肇: 中 頭蓋窩クモ膜の5腫の臨床的分析. 脳神释31 : 205-214, 1979

11）唐沢 淳, 菊池晴彦, 古瀬清次, 石島 裕,

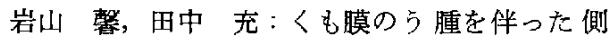
頭葉久損症の1例。脳神経25:1357-1364，1973

12) Karvounis, P. C., Chiu, J. C., Passa, K. \& GilberT, S.: Agenesis of Temporal lobe and Arachnoid Cyst. NY Med J 15:2349-2353, 1970

13) Krawchenko, J. \& Collins, G. H. : Pathology of an arachnoid cyst. $J$ Neurosurg 50: 224-228, 1979

14) Mussella, R. \& Elvidge, A.R.: Parkinsonianlike syndrome caused by cyst in Posterior Fossa. $J$ Neurosurg 21 : 62-65, 1964

15）小原 進, 中川義信, 上田 伸, 松本圭蔵, 谷本邦彦：一畉性双生児の第 1 子にみられた側
頭部くも膜毫腫。腼外 7 : 505-512，1979

16) Ring, B. A. \& Waddington, M.: Primary arachnoid cysts of the sella turcica. $A m J$ Roentgenol 98: 611-615, 1966

17) Robinson, R. G.: Congenital Cysts of the Brain; Arachnoid Malformation. Prog Neurol Surg 4: 133-174, 1971

18) Schachenmayer, W. \& Friede, R. L.: Fine structure of arachnoid cysts. $J$ Neuropathol Exp Neurol 38: 434-446, 1979

19) Sмгтн, R. A. \& Sмiтн, W. A.: Arachnoid cysts of the middle cranial fossa. Surg Neurol $5: 246-$ 252, 1976

20) Smith, R. J. \& ZAcks, D. J.: CT scanning in middle arachnoid malformations. Clin Radiol 29 : $161-169,1978$

21) Starkman, S. P., Prrown, T. C. \& Linell, E. A.: Cerebral arachnoid cysts. $J$ Neurol Neurosurg Psychiatry 17: 484-500, 1958

22）菅沿康雄，岡田洽大，大畑正大，平塚秀雄， 大家一夫, 稻葉 鉌, 松島善治, 谷川公一: 頭 蓋内夕モ膜裹胞. 脂神経30：515-524，1978

23）玉木紀产，峠本勝司，藤原 潔，朝田雅博， 大洞慶郎，白滰邦彦，白方誡弥，松本 悟: 小 罗の側頭部 “arachnoid cysts”. 脳神経 28 : 937950,1976

24) Tiberin, P. \& Crusziewcz, J.: Chronic arachnoidal cysts of the middle cranial fossa and them relation to trauma. $I$ Neurol Neurosurg Psychiatry 24: 86-91, 1961

25）津田敏雄，增田 魅，松本圭葴：老人にみら れた原発性くも膜のら腫の 1 例。畄外 $(10)$ ，揭 載予定

26) Wenman, D. F.: Arachnoidal Cysts in the Syloian Fissure of the Brain. $J$ Neurosurg 22: $185-187,1965$

27) Willson, C. B. \& Bertan, V.: Cerebral leptomeningeal cysts of developmental origin. Am J Roentgenol 98: 570-574, 1966 